$\mathrm{A} \int_{\text {ars }} \mathrm{H}$

Article history :

Received : 19.07.2016

Revised : 22.10 .2016

Accepted : 07.11.2016

Members of the Research Forum

Associated Authors:

${ }^{1}$ Department of Vegetable Science, College of Agriculture, Indira

Gandhi Krishi Vishwavidyalaya, RAIPUR (C.G.) INDIA
Author for correspondence : ANNU VERMA

Pt. K.L.S. College of Horticulture and Research Station (I.G.K.V.), RAJNANDGAON (C.G.) INDIA

Email : annu.verma75@ rediffmail.

com
THEASIAN JOURNALOF HORTICULTURE

Volume 11 | Issue 2 | December, 2016 | 323-328

Visit us -www.researchjournal.co.in
RESEARCH PAPER

DOI : 10.15740/HAS/TAJH/11.2/323-328

\title{
Genetic divergence in vegetable cowpea (Vigna unguiculata L.)
}

\section{RUPESH CHANDRAKAR ${ }^{1}$, ANNU VERMA, J. SINGH ${ }^{1}$ AND N. MEHTA ${ }^{1}$}

ABSTRACT : Twenty one genotypes of vegetable cowpea including checks were planted in Randomized Block Design at the experimental farm of Pt.K.L.S.College of Horticulture and Research Station, Rajnandgaon, during 2015-16. The data recorded on twenty one characters were subjected to analysis of variance. The analysis of variance revealed highly significant differences among the genotypes for all the characters studied except pod width. It indicates that sufficient variability exhisted among the genotype for the mentioned characters. The GCV value was higher for plant height, pod yield per plant indicated that these characters exhibited variability among the genotypes. The highest heritability was recorded for the characters plant height (60DAS), days of maturity, fruiting duration, 50 per cent flowering ,pod setting per cent per plant, 100 dry seed weight, 100-green seed weight. The genetic divergence in the present study observed among 21 genotypes of vegetable cowpea, showed low quantum of divergence and was grouped into five clusters On the basis of $\mathrm{D}^{2}$ analysis. Maximum number of genotypes (9) was accommodated in cluster - II. The average inter and intra cluster divergence (D) values had also been calculated. The intra-cluster distance varied from 0.00 to 5.04. The maximum intra cluster distance was shown by cluster I (5.04) followed by cluster V, cluster II, cluster III and cluster IV. The maximum inter cluster distance was observed in between cluster I and V (5.04). The cluster III showed maximum value for mean green pod yield (146.820g.) followed by cluster IV (146.156g). Crossing between the genotypes of maximum two clusters appeared to be most promising to combine the desirable characters.

KEY WORDS : Genetic divergence, $\mathrm{D}^{2}$ analysis, Vegeatable cowpea (Vigna unguiculata L.)

HOW TO CITE THIS ARTICLE : Chandrakar, Rupesh, Verma, Annu, Singh, J. and Mehta, N. (2016). Genetic divergence in vegetable cowpea (Vigna unguiculata L.). Asian J. Hort., 11(2) : 323-328, DOI : 10.15740/HAS/TAJH/11.2/323-328. 